\section{A Restriction Fragment Length Polymorphism Probe for Early Diagnosis of Gender in Asparagus officinalis L.}

\author{
R. Biffi, F.M. Restivo, and F. Tassi \\ Institute of Genetics, University of Parma, Viale delle Scienze, I-43100 Parma, \\ Italy \\ E. Caporali, A. Carboni, G.P. Marziani, and A. Spada \\ Department of Biology, Section of General Botany, University of Milano, Via \\ Celoria 26, I-20133 Milano, Italy
}

\section{A. Falavigna ${ }^{1}$ \\ Research Institute for Vegetables Crops, Via Paullese 28, Montanaso Lombardo I-20075 Lodi, Italy}

Additional index words. sex determination

\begin{abstract}
The use of a sex-linked molecular marker for early sex diagnosis in the dioecious species Asparagus officinalis $\mathbf{L}$. was evaluated. Screening of random genomic probes as a part of a restriction fragment length polymorphism mapping project resulted in the identification of a sex-linked $(6.9 \mathrm{cM})$ marker. The usefulness of this molecular tool was compared to morphological markers for prediction of gender in several genotypes. The level of polymorphism detected by this probe was high, and the level of incorrect sex attribution, as determined by this method, was low $(\approx 7 \%)$.
\end{abstract}

Asparagus is a dioecious crop plant whose sex determination is genetically regulated (Franken, 1970). The male plant is considered heterogametic, while the female plant is homogametic (Rick and Hanna, 1943). Sex determinants are located on the L5 homomorphic chromosome pair (Loptien, 1979). Male plants are superior to females for important characters such as longevity, growth precocity, and productivity (Benson, 1982). By using andromonoecious plants and in vitro anther culture, plant breeders have developed allmale hybrid varieties (Falavigna et al., 1990; van den Broek and Boouen, 1990). Morphological criteria for preanthesis differentiation of male and female plants have not been identified. For this reason, sex can be determined only after several months of plant growth. Early induction of flowering is possible but not without difficulties (Abe et al., 1990). Therefore, early screening of asparagus plants

Received for publication 28 Nov. 1994. Accepted for publication 18 July 1995. This research was supported by the Ministero delle Risorse Agricole, Alimentari e Forestali, within the framework of the research project, "Development of advanced technologies in agricultural plants." $\delta 47$ probe is available upon request to F.T. The cost of publishing this paper was defrayed in part by the payment of page charges. Under postal regulations, this paper therefore must be hereby marked advertisement solely to indicate this fact.

${ }^{1}$ To whom reprint requests should be addressed. for sex expression is important in breeding programs. At present, males and females can be distinguished at flowering time, but the XY or YY status of male plants can be inferred only by observation of gender in $F_{1}$ progeny.

We have recently developed a partial genetic map for asparagus consisting of 12 linkage groups (Restivo et al., 1995). A malate dehydrogenase isozyme (Maestri et al., 1991) and three restriction fragment length polymorphism (RFLP) markers (Restivo et al., 1995) are associated with the sex-determining factors. The distance between the nearest marker ( $\delta 47)$ and the sex determinants was estimated to be $6.9 \mathrm{cM}$. In this paper, we have extended the analysis of this sex-linked molecular marker and tested its usefulness for early gender analysis of asparagus seedlings.

\section{Material and Methods}

Asparagus parental genotypes were obtained from the Research Institute for Vegetable Crops (Section of Montanaso Lombardo, Lodi, Italy). These doubled haploid lines (clones) were obtained from anther culture (Falavigna et al., 1990). Since the male parents are homozygous at the sex determination locus and $F_{1}$ progeny are male, linkage analysis was performed on backcross progeny (Table 1). For tests of probe efficiency, 16 double haploid clones were used [seven males (1559, $127,1762,1979,4093,3528,1666)$ and nine females (1396, 1796, 46, 61, 1867, 1871, 109, 2668, 1847)].

DNA was extracted from $1 \mathrm{~g}$ of frozen cladophylls following the method of Dellaporta et al. (1985) with minor modifications; where urea $(8 \mathrm{M})$ was added to the extraction buffer, and after phenol/chloroform extraction, polysaccharides were eliminated by a CTAB procedure (Doyle and Doyle, 1990).

Sample DNA $(5 \mu \mathrm{g})$ was digested with restriction enzymes (BglII, DraI, EcoRI, EcoRV, and HindIII), subjected to electrophoresis on agarose $(0.8 \%)$ gels, and vacuum blotted onto Hybond $\mathrm{N}^{+}$membranes (Amersham, Bucks, U.K.). The DNA probe was labeled by the rediprime labeling kit (Amersham, Bucks, U.K.), hybridized to the filters for $20 \mathrm{~h}$ at $65 \mathrm{C}$ according to Church and Gilbert (1984), and then blots were autoradiographically exposed for 2 to 7 days at $-80 \mathrm{C}$. The hybridization patterns of parentals and $\mathrm{BC}_{1}$ DNAs were compared and recorded as $\mathrm{P}$ or M phenotypes.

\section{Results and Discussion}

Male and female doubled haploid parents of cross D had differing hybridization patterns when DNA was digested with $B g l \mathrm{II}$ and hybridized to probe $\delta 47$ (Fig. 1). The male parent (not shown) displayed a 4100-bp band, whereas the female parent displayed a 3800-bp band. The $\mathrm{F}_{1}$ progeny exhibited both bands. Backcross progeny segregated in a 1:1 ratio typical of a simple Mendelian trait. The RFLP patterns of 20 of $66 \mathrm{BC}_{1}$ progeny analyzed are provided (Fig. 1). The sex linkage of this marker is evident as all nine female plants had only the 3800 -bp band, while 10 of 11 male plants had both bands. Of the $66 \mathrm{BC}_{1}$ progeny, 62 had the expected banding pattern (Table 1, cross D).

To evaluate the possibility of using probe $\delta 47$ as a molecular tool for early gender analysis, DNA of progeny from various crosses were subjected to single digestion with various restriction enzymes using the same approach (Table 1). We found 1) the level of polymorphism detectable with probe $\delta 47$ is high, as polymorphism was present in each cross when DNA was digested with HindIII; 2) polymorphic patterns obtained in four crosses (D, G, E, S) using the same restriction enzyme (HindIII) segregated as sex-linked markers in $\mathrm{BC}_{1}$ progeny; 3 ) consistent presence of codominant $\mathrm{F}_{1}$ phenotypes and predictable Mendelian segregation in $\mathrm{BC}_{1}$ progenies; and 4) polymorphic patterns obtained in the same cross (cross D) by single digestion using various restriction enzymes ( $B g l \mathrm{II}$, EcoRV, HindIII) co-segregated as sex-linked loci in the $\mathrm{BC}_{1}$ progeny.

The use of probe $\delta 47$ led to an incorrect gender prediction for 13 of $181 \mathrm{BC}_{1}$ progeny (7.2\% recombinants, Table 1$)$.

Another test for the efficiency of this probe could be made by evaluating the level of polymorphism detectable in a population of male and female doubled haploid plants. Samples of DNA from seven males and nine females coming from a collection of double haploid plants were digested separately with $B g l \mathrm{II}, \mathrm{DraI}$, and EcoRV, and hybridized with probe $\delta 47$. The banding pattern of each of the female plants was compared with that of each of the male plants (data not shown).

The results obtained from these compari- 


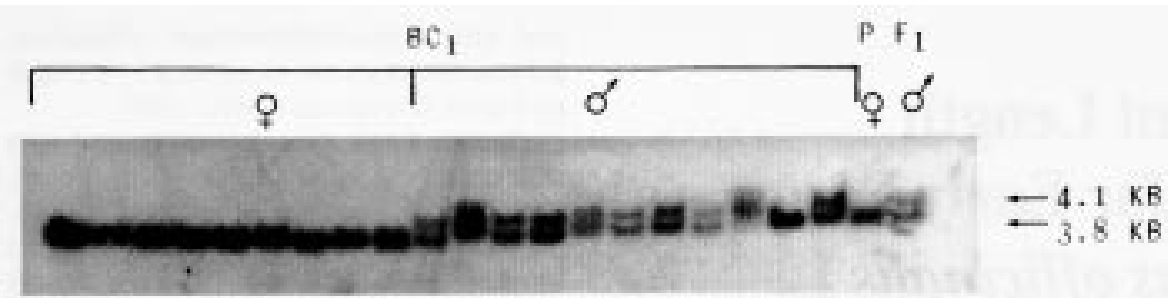

Fig. 1. Autoradiography of $\delta 47$ probe hybridization to DNA (DNA digested with $B g l I I$ ) of 20 asparagus BC progeny from cross $\mathrm{D}\left(\mathrm{BC}_{1}=\right.$ male and female backcross progeny, $\mathrm{P}=$ female parent, and $\mathrm{F}_{1}=\mathrm{F}_{1}$ progeny).

Table 1. Linkage analysis of probe $\delta 47$ to Asparagus officinalis sex.

\begin{tabular}{lcrrrrrrr}
\hline \hline & Restriction & \multicolumn{9}{c}{ BC progeny phenotypes $^{2}$} & & \multicolumn{2}{c}{$\begin{array}{c}\text { Recombinants } \\
\text { Cnzyme }\end{array}$} & m/P & $\mathrm{m} / \mathrm{M}$ & $\mathrm{f} / \mathrm{P}$ & $\mathrm{f} / \mathrm{M}$ & Total & $\chi^{2}$ & $(\%)$ \\
\hline $\mathrm{D}$ & $\mathrm{H}, \mathrm{E}, \mathrm{B}$ & 29 & 1 & 3 & 33 & 66 & $47.6^{* *}$ & 6.1 \\
$\mathrm{G}$ & $\mathrm{H}$ & 22 & 1 & 1 & 21 & 45 & $33.8^{* * *}$ & 4.4 \\
$\mathrm{E}$ & $\mathrm{H}$ & 9 & 4 & 0 & 19 & 32 & $15.0^{* * *}$ & 12.5 \\
$\mathrm{~S}$ & $\mathrm{H}$ & 15 & 3 & 0 & 20 & 38 & $24.1^{* *}$ & 7.9 \\
Pooled $^{\mathrm{x}}$ & & 75 & 9 & 4 & 93 & 181 & $129.3^{* *}$ & 7.2 \\
\hline
\end{tabular}

${ }^{2} \mathrm{~m}=$ male, $\mathrm{f}=$ female $; \mathrm{m} / \mathrm{P}$ and $\mathrm{f} / \mathrm{M}=$ parental classes and $\mathrm{m} / \mathrm{M}$ and $\mathrm{f} / \mathrm{P}=$ recombinant classes. $\mathrm{BC}$ progeny where: $\mathrm{D}=1396 \mathrm{f} \times(1396 \mathrm{f} \times 1979 \mathrm{~m}) ; \mathrm{E}=1796 \mathrm{f} \times(1796 \mathrm{f} \times 1559 \mathrm{~m}) ; \mathrm{G}=109 \mathrm{f} \times(109 \mathrm{f} \times 127 \mathrm{~m}) ; \mathrm{S}=$ $46 \mathrm{f} \times(46 \mathrm{f} \times 127 \mathrm{~m})$

${ }^{\mathrm{y}} \mathrm{H}=H i n d \mathrm{III}, \mathrm{E}=E c o \mathrm{RV}$, and $\mathrm{B}=B g l \mathrm{II}$.

${ }^{x}$ Heterogeneity $\chi^{2}(3 \mathrm{df})$ where 3.022 is nonsignificant.

**Significant at $P<0.01$.

sons [63 $(7 \times 9)$ for each enzyme] were either male and female clones showing a dissimilar pattern (indicating a polymorphism) or male and female clones demonstrating similar patterns (absence of polymorphism).

In the 16 parentals analyzed, which could correspond to 63 possible crosses, a polymorphism between male and female plants is revealed at least with one restriction enzyme (that may be either $E c o \mathrm{RV}, \operatorname{DraI}$, or $B g l \mathrm{II}$ ).

This clonal comparison is a good indication that a screening for polymorphism in any random cross will require the use of only a small set of restriction enzymes to be successful.

These data $\left(\mathrm{BC}_{1}\right.$ and clonal comparison) indicate that the probe $\delta 47$ could be used for gender prediction in asparagus.

\section{Literature Cited}

Abe, T., T. Kamaya, and H. Iwamura. 1990. Flower induction by triazines, ureas and carbamates in seedling of asparagus. Acta Hort. 271:491-495.

Benson, B.L. 1982. Sex influence of foliar trait morphology inAsparagus. HortScience 17:625627.

Church, G.M. and W. Gilbert. 1984. Genomic sequencing. Proc. Natl. Sci. USA 81:1991-1995.

Dellaporta, S.L., J. Wood, and J.B. Hicks. 1985. Molecular biology of plants. Cold Spring Harbor Lab., Cold Spring Harbor, N.Y. p. 36-37.

Doyle, J.J. and J.L. Doyle. 1990. Isolation of plant DNA from fresh tissue. Focus 12:13-15.

Falavigna, A., P.E. Casali, and M.G. Tacconi. 1990. Potential of in vitro anther culture technique for asparagus breeding in Italy. Acta Hort. 271:3946.

Franken, A.A. 1970. Sex characteristics and inheritance of sex in asparagus (Asparagus officinalis L.). Euphytica 19:277-287.

Loptien, H. 1979. Identification of sex chromosome pair in asparagus (Asparagus officinalis L.). Z. Pflanzenzuchtg. 82:162-173.

Maestri, E., F.M. Restivo, G.P. Marziani Longo, A. Falavigna, and F. Tassi. 1991. Isozyme gene markers in the dioecious species Asparagus officinalis L. Theor. Appl. Genet. 81:613-618.

Restivo, F.M., F. Tassi, R. Biffi, A. Falavigna, E. Caporali, A. Carboni, M.L. Doldi, A. Spada, and G.L. Marziani. 1995. Linkage arrangement of RFLP loci in progenies from crosses between doubled haploid Asparagus officinalis L. clones. Theor. Appl. Genet. 90:124-128.

Rick, C.M. and G.C. Hanna. 1943. Determination of sex in Asparagus officinalis L. Amer. J. Bot. 30:711-714.

van den Broek, J.H. and P.H. Boonen. 1990. Today's asparagus breeding in the Netherlands. Acta Hort. 271:33-38. 